\title{
Blood pressure, ethnic group, and salt intake in Belize
}

\author{
DAVID SIMMONS \\ From the Cambridge Belize Expedition 1980
}

SUMmARY A total of 1316 individuals were studied in seven villages in Belize, Central America. This represented $92 \%$ of the area population aged over 18 . Generally, they were members of three ethnic groups-Maya, Spanish, and Creole. The systolic and diastolic IV and V blood pressures were recorded using standardised procedure. Significant differences in blood pressure, weight, and obesity were found between ethnic groups in both sexes, Creoles having higher means than the other groups. Significant relationships with blood pressure were found with obesity, age, and number of children. An early morning urine specimen was obtained from a random $50 \%$ of the men, and only in Creoles was there an association between raised blood pressure and sodium/potassium urinary excretion ratio.

The small country of Belize, Central America (population 150000 ), provides an opportunity to study the pattern of blood pressure distribution in several ethnic groups living in close association. The Cayo district in the west of the country includes three such groups-Maya, Spanish, and Creole. The district is about 30 miles from the Caribbean Sea at its nearest point with mountains to the south and tropical jungle in all other directions. Communications are by a major road, the Belize Road, running from the coast, and the River Belize.

No previous study of hypertension in Belize has been reported, and although work on other Caribbean peoples of Negro extraction has been carried out, ${ }^{1-4}$ little has been undertaken on Maya ${ }^{5}$ or Spanish (Ladinos) groups. The purpose of this survey was to measure the distribution of blood pressure in three ethnic groups and to investigate relations between blood pressure, anthropometric measurements, and urinary electrolyte excretion within village and ethnic groups.

\section{Subjects}

The electoral roll was used to select the seven largest villages along the Belize Road, Cayo District, to achieve a target sample of 1500 (1\% total Belizean population). Within each village local inhabitants, serving as interpretors, helped to compile a list of all those aged over 18 living in each house. This census was subsequently checked against a house-to-house survey, which made it possible to complete a questionnaire for each villager, preventing duplication and omission. All subjects were aware of their ages, most having a birth certificate.
Allocation of an individual to a particular ethnic group was based on the first language of the grandparents: Creoles had one or more who spoke Creole; all the grandparents of Mayas spoke Mayan and the Spanish had one or more grandparents who spoke Spanish but with no grandparent who spoke Creole. Villages were characterised by those groups who made up $20 \%$ or more of the village populationfo they then fell into four types: Creole ( 2 villages); Spanish/Creole (2 villages), Maya (1 village), and Spanish/Maya (2 villages). The Creole and Spanish/Creole villages were of linear type along the Belize Road; the Spanish/Maya and Maya villages were nucleated villages.

The men were mainly farmers, growing the staple crop, maize, in family plots. Some of these plots were a considerable distance from the village. Women were almost entirely occupied with housework.

\section{Method}

Seven university students (five medical) were trained to use the Hawkesley random zero sphygmomanometer ${ }^{6}$ by the Medical Research Council hypertension trials training officer. Before departure an observer comparison was made with 12 subjects, and no statistically significant difference between observers was detected.

The procedure used was fully standardised. The subject sat on the floor of his own home with his back to the wall and legs out straight. The left elbow rested on a custom-built arm rest such that the cuff was at about the level of the heart. Surrounding clothing was removed and large cuffs were used for over-sized arms. During a timed 10 -minute rest period the 
observer completed a questionnaire including age, name, date of birth, marital status, number of children in the household, parental and grandparental first language, occupation, hours worked, and the number of people over 18 who regularly slept in the house.

Two successive measurements of systolic, diastolic IV (D4BP), and diastolic V (D5BP) blood pressures were taken, and the true blood pressure was taken as the mean of the two values. If there was a difference in systolic blood pressure of $20 \mathrm{~mm} \mathrm{Hg}$ or greater, or $10 \mathrm{~mm} \mathrm{Hg}$ or greater in the D4BP or D5BP, the recording was repeated once or twice more and the two closest values used. After the recording had been taken, questions about previous treatment for hypertension and smoking habits were asked and anthropometric measurements (pulse, standing height, weight, and arm circumference) made using standardised procedures. ${ }^{7}$

Urine samples were requested from men allotted even subject numbers, and the first specimen passed in the morning was collected of which $25 \mathrm{ml}$ aliquots were preserved with $0.6 \mathrm{ml} \mathrm{H}_{2} \mathrm{SO}_{4}$ and brought back to England for analysis. Sodium and potassium contents were assessed by flame photometry, and creatinine by the Jaffe reaction.

Statistics were computed using the Fortran based package, Genstat, on the Cambridge IBM 370/165 computer. Individuals with a D4BP over $100 \mathrm{~mm} \mathrm{Hg}$ were referred to the district medical officer for treatment.

\section{Results}

Of the 1430 individuals enumerated in the seven villages, 1315 (92\%) agreed to participate in the survey (table 1). Of the 307 men randomly selected for urine sampling, 293 (95\%) complied. One sample was suspected of contamination and was not included in the analyses.

Figures 1 and 2 illustrate the relation between blood pressure and age by sex and ethnic groups. Table 2 shows anthropometric and blood pressure parameters. The mean ages for men were not significantly different between ethnic groups, but the
Mayan women showed a mean age significantly older $(p<0 \cdot 01)$ than that of the other two groups. Creoles were significantly heavier (both sexes $p<0.001$ ), and had greater arm circumference (both sexes $p<0.001$ ) than the other two groups. Spanish men had a significantly lower body mass index $(p<0.05)$ and the Creoles had significantly higher pulse rate (men $\mathrm{p}<0.01$, women $\mathrm{p}<0 \cdot 01$ ).

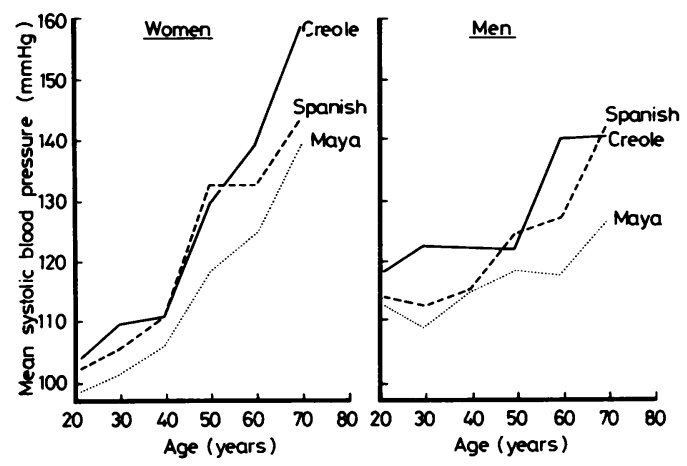

Fig 1 Relation between systolic blood pressure and age by sex and ethnic group.

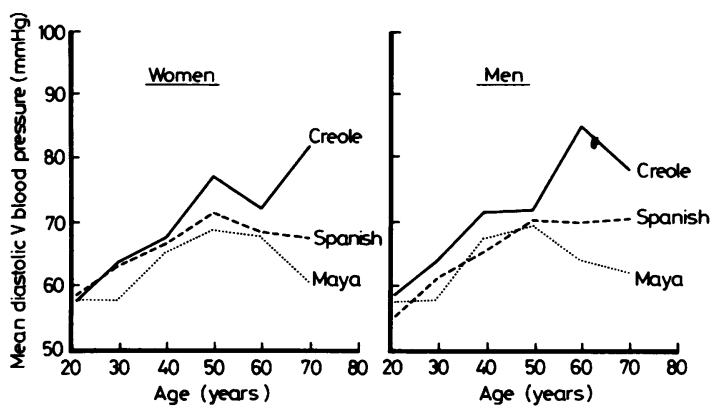

Fig 2 Relation between diastolic $V$ blood pressure and age by sex and ethnic group.

Table 1 Population enumerated and examined by sex and ethnic group

\begin{tabular}{|c|c|c|c|c|c|c|}
\hline & \multirow[b]{2}{*}{ Sex } & \multicolumn{5}{|c|}{ Ethnic group } \\
\hline & & Creole & Maya & Spanish & Other & All \\
\hline Enumerated & $\begin{array}{l}\mathbf{M} \\
\mathbf{F}\end{array}$ & 284 & 170 & 240 & 28 & 722 \\
\hline Examined & $\mathbf{M}$ & 247 & 157 & 209 & $\begin{array}{l}24 \\
25\end{array}$ & 638 \\
\hline$\%$ examined & $\begin{array}{l}\mathbf{F} \\
\mathbf{M} \\
\mathbf{F}\end{array}$ & $\begin{array}{r}264 \\
87 \\
96\end{array}$ & $\begin{array}{r}143 \\
92 \\
96\end{array}$ & $\begin{array}{r}248 \\
87 \\
96\end{array}$ & $\begin{array}{l}23 \\
89 \\
96\end{array}$ & $\begin{array}{r}678 \\
88 \\
96\end{array}$ \\
\hline
\end{tabular}


Table 2 Mean and (standard deviation) of anthropometric and blood pressure measurements by sex and ethnic group

\begin{tabular}{|c|c|c|c|c|c|c|c|c|}
\hline \multirow[b]{2}{*}{ Measurement } & \multirow[b]{2}{*}{ Sex } & \multicolumn{2}{|l|}{ Creole } & \multicolumn{2}{|l|}{ Maya } & \multicolumn{2}{|l|}{ Spanish } & \multirow{2}{*}{$\begin{array}{l}\text { Significance of } \\
\text { differences }\end{array}$} \\
\hline & & Mean & $S D$ & Mean & $S D$ & Mean & $S D$ & \\
\hline Age (years) & $\begin{array}{l}\mathbf{M} \\
\mathbf{F}\end{array}$ & $\begin{array}{l}38 \cdot 9 \\
35 \cdot 1\end{array}$ & $\begin{array}{l}(18 \cdot 0) \\
(16 \cdot 8)\end{array}$ & $\begin{array}{l}39.4 \\
42.0\end{array}$ & $\begin{array}{l}(17 \cdot 2) \\
(17 \cdot 3)\end{array}$ & $\begin{array}{l}38.4 \\
36.4\end{array}$ & $\begin{array}{l}(15.4) \\
(15.5)\end{array}$ & $\underset{* * *}{N S}$ \\
\hline Weight (kg) & $\begin{array}{l}\mathbf{M} \\
\mathbf{F}\end{array}$ & $\begin{array}{l}67.9 \\
62.2\end{array}$ & $\begin{array}{l}(12.9) \\
(13.9)\end{array}$ & $\begin{array}{l}56.2 \\
53.4\end{array}$ & $\begin{array}{r}(8 \cdot 3) \\
(10 \cdot 9)\end{array}$ & $\begin{array}{l}58 \cdot 3 \\
54 \cdot 5\end{array}$ & $\begin{array}{l}(10.1) \\
(10.8)\end{array}$ & $* * *$ \\
\hline BMI $\left(\mathbf{k g} / \mathrm{cm}^{2}\right)$ & $\begin{array}{l}\mathbf{M} \\
\mathbf{F}\end{array}$ & $\begin{array}{l}2 \cdot 35 \\
2 \cdot 51\end{array}$ & $\begin{array}{l}(0.42) \\
(0.55)\end{array}$ & $\begin{array}{l}2.31 \\
2 \cdot 51\end{array}$ & $\begin{array}{l}(0.35) \\
(0.45)\end{array}$ & $\begin{array}{l}2.24 \\
2.45\end{array}$ & $\begin{array}{l}(0.41) \\
(0.46)\end{array}$ & NS \\
\hline Arm girth (cm) & $\begin{array}{l}\mathbf{M} \\
\mathbf{F}\end{array}$ & $\begin{array}{l}28 \cdot 4 \\
28 \cdot 4\end{array}$ & $\begin{array}{l}(3 \cdot 2) \\
(4 \cdot 5)\end{array}$ & $\begin{array}{l}26 \cdot 3 \\
26 \cdot 4\end{array}$ & $\begin{array}{l}(2.2) \\
(3.4)\end{array}$ & $\begin{array}{l}26 \cdot 2 \\
26 \cdot 6\end{array}$ & $\begin{array}{l}(2.7) \\
(3.4)\end{array}$ & $* * * *$ \\
\hline Pulse beats/min & $\begin{array}{l}\text { M } \\
\text { F }\end{array}$ & $\begin{array}{r}72 \cdot 5 \\
77 \cdot 6\end{array}$ & $(11 \cdot 0)$ & $\begin{array}{r}67 \cdot 8 \\
74 \cdot 3\end{array}$ & $(10 \cdot 9)$ & $\begin{array}{r}68 \cdot 6 \\
76.0\end{array}$ & $(10.6)$ & $* * *$ \\
\hline SBP (mm Hg) & $\begin{array}{l}\text { M } \\
\mathbf{F}\end{array}$ & $\begin{array}{l}124 \cdot 2 \\
115 \cdot 8\end{array}$ & $\begin{array}{l}(17 \cdot 0) \\
(19 \cdot 8)\end{array}$ & $\begin{array}{l}115 \cdot 2 \\
112 \cdot 0\end{array}$ & $\begin{array}{l}(12 \cdot 9) \\
(17 \cdot 9)\end{array}$ & $\begin{array}{l}118 \cdot 6 \\
114 \cdot 0\end{array}$ & $(15 \cdot 5)$ & NS \\
\hline D(4)BP (mm Hg) & $\begin{array}{l}\mathbf{M} \\
\mathbf{F}\end{array}$ & $\begin{array}{l}72 \cdot 2 \\
68 \cdot 6\end{array}$ & $\begin{array}{l}(14 \cdot 1) \\
(14 \cdot 7)\end{array}$ & $\begin{array}{l}68 \cdot 8 \\
67 \cdot 2\end{array}$ & $\begin{array}{l}(10.8) \\
(11.9)\end{array}$ & $\begin{array}{l}70 \cdot 1 \\
66 \cdot 8\end{array}$ & $(11 \cdot 5)$ & NS \\
\hline $\mathrm{D}(5) \mathrm{BP}(\mathrm{mm} \mathrm{Hg})$ & $\begin{array}{l}\mathbf{M} \\
\mathbf{F}\end{array}$ & $\begin{array}{l}66 \cdot 6 \\
65 \cdot 4\end{array}$ & $\begin{array}{l}(14 \cdot 0) \\
(15 \cdot 3)\end{array}$ & $\begin{array}{l}63 \cdot 4 \\
62 \cdot 7\end{array}$ & $\begin{array}{r}(10.4) \\
(9.6)\end{array}$ & $\begin{array}{l}63 \cdot 8 \\
64 \cdot 1\end{array}$ & $\begin{array}{l}(12 \cdot 2) \\
(11 \cdot 8)\end{array}$ & NS \\
\hline
\end{tabular}

BMI = Body mass index. $* * * p<0.001 ; * * p<0.01 ; * p<0.05$.

Significant differences between ethnic groups in all blood pressure measurements for men were shown (SBP p <0.001; D4BP p <0.05; D5BP p $<0.05$ ) with Creoles having the highest and Mayas the lowest blood pressures. Women showed no significant differences in blood pressure between ethnic groups, but after adjustment for age by analysis of covariance $^{8}$ they showed significant differences in blood pressure, which was the same pattern as in men with Creoles highest and Maya lowest (table 3). The variance of blood pressure was consistently greater in Creoles than in the other two groups.

Table 3 Age-adjusted blood pressure in women

\begin{tabular}{|c|c|c|c|c|}
\hline $\begin{array}{l}\text { Measurement } \\
(\mathrm{mm} \mathrm{Hg})\end{array}$ & Creole & Maya & Spanish & $\begin{array}{l}\text { Significance of } \\
\text { differences }\end{array}$ \\
\hline $\begin{array}{l}\text { SBP } \\
D(4) B P \\
D(5) B P\end{array}$ & $\begin{array}{r}117 \cdot 6 \\
69 \cdot 2 \\
66 \cdot 1\end{array}$ & $\begin{array}{r}107 \cdot 8 \\
65 \cdot 9 \\
61 \cdot 3\end{array}$ & $\begin{array}{r}114.6 \\
67.0 \\
64.4\end{array}$ & $\begin{array}{l}* * * \\
* \\
*\end{array}$ \\
\hline
\end{tabular}

*** $p<0.001 ;{ }^{* *} p<0.01 ;{ }^{*} p<0.05$.

Most Mayan and Spanish men (85.4\% and $84.2 \%$ respectively) were farmers while only $51.8 \%$ of Creole men were employed as such. Of Creole men, $36.8 \%$ were employed in service industries - for instance, mechanics, plumbers, tailors. An analysis of covariance showed no significant differences in blood pressure after age between the two occupational groups in Creoles.

Neither the Creole nor Spanish differed significantly in blood pressure between villages after accounting for age. Mayas, however, differed between villages in systolic blood pressure in women $(p<0.05)$ and in the diastolic blood pressure in men (D4BP $p<0.01$; D5BP, $p<0.05$ ). No definite trend or reason for this finding could be ascertained from the data collected. Smoking habits and occupation showed no relation with blood pressure in any ethnic group. Weight, obesity (measured as the body mass index), and arm circumference showed positive correlations with diastolic blood pressure of varying significance depending on sex and ethnic group. Significant negative correlations with the number of children were found in women (Creole $p<0.05$ Spanish $\mathrm{p}<0.001$; Maya $\mathrm{p}<0.01)$ and also in mete (Creole $\mathrm{p}<0.05$; Maya $\mathrm{p}<0.05)$, after accounting for age.

URINARY ELECTROLYTES IN RELATION TO BLOOD PRESSURE

An analysis of variance showed no significant difference in blood pressure between those who gave and those who did not give urine samples. Urinary results are shown in table 4 and significant difference between ethnic groups were found for creatinine $(\mathrm{p}<0.001)$, sodium $(\mathrm{p}<0.001)$, and potassium $(\mathrm{p}<0.05)$ concentrations and for early morning urine volume $(p<0.05)$. Although no significant differences in sodium:creatinine urinary excretion ratio $(\mathrm{Na} / \mathrm{Cr}$ ratio) was found between ethnic groups, the potassium:creatinine urinary excretion ratio $(\mathrm{K} / \mathrm{Cr}$ ratio) differed significantly $(\mathrm{p}<0.01)$. In the under-40 age group the sodium:potassium urinary excretion ratio $(\mathrm{Na} / \mathrm{K}$ ratio) was significantly higher $(p<0.05)$ in Creoles than in the other two groups.

Partial correlation ${ }^{y}$ permits the prediction of independent and dependent variables with the effect of control variables removed. This is carried out by calculating the difference between the original value and the value predicted by the control variable, and is known as the residual value. Figure 3 illustrates the regression lines of the residual values of systolic blood pressure on age and of $\mathrm{Na} / \mathrm{K}$ ratio on age for each ethnic group. After removing the effect of age in 
Table 4 Urinary excretion values in men

\begin{tabular}{|c|c|c|c|c|c|c|c|c|}
\hline \multirow[b]{3}{*}{$\begin{array}{l}\text { Sodium (mmol/l) } \\
\text { Potassium }(\mathrm{mmol} / \mathrm{l}) \\
\text { Creatinine (mmol/l) } \\
\text { Sodium:creatinine ratio } \\
\text { Potassium:creatinine ratio } \\
\text { Sodium:potassium ratio } \\
\text { Volume }\end{array}$} & \multicolumn{2}{|l|}{ Creole } & \multicolumn{2}{|l|}{ Maya } & \multicolumn{2}{|c|}{ Spanish } & \multirow{2}{*}{$\frac{F}{11.50}$} & \multirow{2}{*}{$\begin{array}{l}\begin{array}{l}\text { Significance of } \\
\text { differences }\end{array} \\
* *\end{array}$} \\
\hline & \multicolumn{2}{|c|}{$\begin{array}{c}\text { Mean } S D \\
\quad(n=123)\end{array}$} & \multicolumn{2}{|c|}{$\begin{array}{r}\text { Mean } S D \\
(n=81)\end{array}$} & \multicolumn{2}{|c|}{$\begin{array}{r}\text { Mean } \quad S D \\
(n=88)\end{array}$} & & \\
\hline & $\begin{array}{r}145 \cdot 2 \\
29.7 \\
17 \cdot 7 \\
10 \cdot 0 \\
1 \cdot 8 \\
9 \cdot 2 \\
267\end{array}$ & $\begin{array}{r}(63 \cdot 7) \\
(22 \cdot 5) \\
(9 \cdot 5) \\
(6 \cdot 1) \\
(1 \cdot 3) \\
(10 \cdot 8) \\
(178)\end{array}$ & $\begin{array}{r}104.8 \\
21 \cdot 8 \\
11 \cdot 0 \\
11 \cdot 4 \\
2.1 \\
7 \cdot 1 \\
210\end{array}$ & $\begin{aligned}(65 \cdot 8) \\
(17 \cdot 7) \\
(7 \cdot 1) \\
(7 \cdot 4) \\
(1 \cdot 5) \\
(5 \cdot 3) \\
(151)\end{aligned}$ & $\begin{array}{r}111.9 \\
31.4 \\
13 \cdot 4 \\
10.3 \\
2.5 \\
5.8 \\
231\end{array}$ & $\begin{array}{r}(64 \cdot 7) \\
(24 \cdot 6) \\
(7 \cdot 4) \\
(7 \cdot 8) \\
(1.9) \\
(5 \cdot 4) \\
(164)\end{array}$ & $\begin{array}{r}11 \cdot 50 \\
4 \cdot 42 \\
17 \cdot 21 \\
0 \cdot 90 \\
5 \cdot 25 \\
1.83 \\
3.08\end{array}$ & $\begin{array}{l}* * * \\
* * * \\
\text { NS } \\
\text { N** } \\
\text { NS }\end{array}$ \\
\hline
\end{tabular}

*** $p<0.001 ; * * p<0.01 ; * p<0.05$.

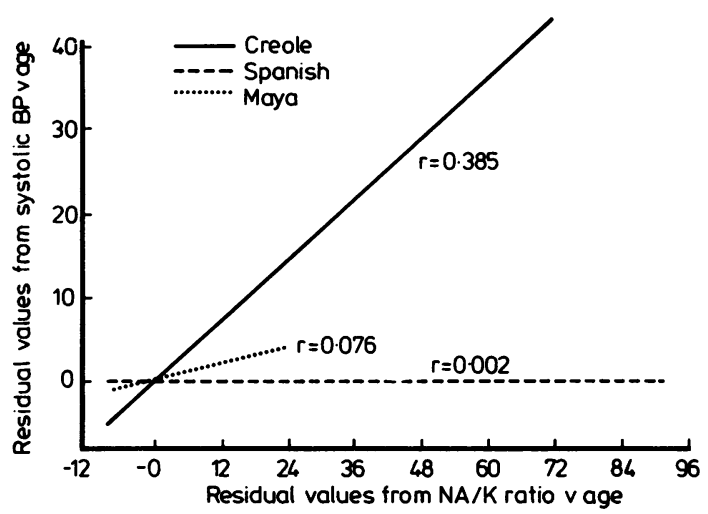

Fig 3 Partial correlation of systolic blood pressure against sodium potassium urinary excretion ratio after age in men.

this way, the Creole men showed a significant correlation $(r=0.385, p<0.001)$ of systolic blood pressure with the $\mathrm{Na} / \mathrm{K}$ ratio. No comparable relation was found in the other two ethnic groups. The $\mathrm{Na} / \mathrm{Cr}$ and $\mathrm{K} / \mathrm{Cr}$ ratios failed to show any significant relationships with blood pressure after age.

\section{Discussion}

The aim of this study was to compare the blood pressure of the different ethnic groups in the same environment; significant differences in blood pressure were found among the three ethnic groups with Creoles having a higher mean blood pressure than those of the other groups. The differences in blood pressure among women were obscured by age differences, but an analysis of covariance showed significant differences.

Variables that could contribute to the pattern of blood pressures within and the differences between ethnic groups were also examined. In Mayan and Spanish men the absence of differences between occupations could be due to the preponderance of farmers in the population and hence only a small sample of those of other occupations. In Creoles the absence of difference between agricultural and non-agricultural workers possibly reflects their similar diet and life style.

The effect of parity and hence family size has been reported before. ${ }^{12}$ The relationship of blood pressure with weight and obesity has also been known for some time, ${ }^{13} 14$ but the mechanism remains obscure. There is often an increase in recorded blood pressure with increased arm circumference with the same sized cuff. ${ }^{15}$ This effect was minimised by using larger cuffs for oversized arms, but no comparison of the two sizes of cuff and their effects on recorded blood pressure were undertaken.

Only Mayas were shown to differ significantly in blood pressure between villages and no reason for this was found. Populations of the same ethnic group in different locations have often been reported to show different blood pressure distributions, ${ }^{16-18}$ but these are usually associated with acculturation and the adoption of different diets and life styles.

The high response rates achieved in this survey compare favourably with those in similar surveys. ${ }^{19} \mathrm{~A}$ major problem was the assessment of ethnic group membership. Classification by first parental language is an established anthropological method, but in this survey only the Mayas constitute a homogenous group. Intermarriage, although infrequent, made definition of the Creole and Spanish groups difficult. The number of subjects in this survey did not permit further subclassification of ethnic groups based on the language of all four grandparents.

It was decided to assess electrolyte intake from urine output because of the obvious qualitative nature of dietary surveys. It was hoped to take 24-hour samples but conditions made success with this unlikely. Nevertheless, for the purpose of comparison of ethnic groups the method used was considered adequate. The samples were collected overnight and have been shown to correlate well with the 24-hour collection. ${ }^{10}$

The significant differences in urinary electrolyte concentrations could be due to the significant 
differences in volume, and because no information on the 24-hour urinary output of creatinine in the subjects was available, statistical analysis has been applied solely to the urinary excretion ratios.

The mean of the sum of urinary excretion ratios for each subject differs noticeably from that derived from the mean urinary excretion values. This is due to the former method of estimation giving greater weight to larger values in the numerator and smaller values in the denominator. This variance is illustrated by the large standard deviations of the excretion ratios. Such extremes are eliminated by "pooling" the urinary sodium, potassium, and creatinine values and calculating the respective ratios.

The major finding in this survey is the correlations of systolic blood pressure with the $\mathrm{Na} / \mathrm{K}$ ratio in Creole men. This relation shown in Creoles but not in the other two ethnic groups, may be due to the larger variance in blood pressure in Creoles, constancy of diet, different electrolyte intake, different inherent responses to electrolytes, or some combination of these. Different dietary habits are suggested by the differences in $\mathrm{K} / \mathrm{Cr}$ and $\mathrm{Na} / \mathrm{K}$ ratios, and to some degree by the sodium and potassium values. The significant difference between ethnic groups of the $\mathrm{K} / \mathrm{Cr}$ ratio is mainly attributable to the high value in the Spanish group. It has been suggested that Negroes are more sensitive to salt than other groups ${ }^{1}$; hence both differences in electrolyte intake and inherent responses are likely to be implicated.

I thank Dr T W Davies and Dr D R R Williams at the department of community medicine, New Addenbrook's Hospital, Cambridge, Dr W E Miall at Northwick Park, Professor G A Rose at the London School of Hygiene and Tropical Medicine, and Professor J M Ledingham, London Hospital, for encouragement and also Dr N Galwey, department of applied biology, Cambridge University, for his guidance with computing and statistics, and the other members of the Cambridge Belize Expedition 1980. I also thank the clinical biochemistry department, New Addenbrook's Hospital, for their analyses, Gelman Hawkesley for the loan of their excellent machines, and all other sponsors and advisors, both in the United Kingdom and Belize.
Requests for reprints to: Mr D Simmons, 131 Western Avenue, Acton, London W3.

\section{References}

${ }^{1}$ Moser M, Morgan R, Hale M, et al. Epidemiology of hypertension with particular reference to the Bahamas. Am J Cardiol 1959; 4: 727-33.

${ }^{2}$ Schneckloth RE, Corcoran AC, Stuart KL, Moore FE Arterial pressure and hypertensive disease in a West Indian Negro population: report of a survey in St Kitts. Am Heart J 1962; 63: 607-28.

${ }^{3}$ Humphries SV. A study of hypertension in the Bahamas. $S$ Afr Med J 1957; 31: 694-9.

${ }^{4}$ Miall WE, Kass EH, Ling J, Stuart KL. Factors influencing arterial pressure in the general population in Jamaica. Br Med J 1962; ii: 497-506.

${ }^{5}$ Hoobler SW, Arbor A, Tejada C, Guzman M, Pardo A Influence of nutrition and acculturation on the blood pressure levels and changes with age in the Highland Guatemalan Indians. Circulation 1965; 32 suppl 11 : 116.

${ }^{6}$ Wright BM, Dore CF. A random zero device. Lancet 1970; i: 337-8.

${ }^{7}$ Rose GA, Blackburn H. Cardiovascular survey methods. Geneva: World Health Organisation, 1968: 58.

${ }^{8}$ Cochran WG, Cox GM. Experimental designs. New York: Wiley, 1957; 82-91.

${ }^{9}$ Kendall MG, Stuart A. The advanced theory of statistics. Vol 2. London: Griffin, 1961: 330-4.

${ }^{10}$ Langford HG, Watson RL, Douglas BH. Factors affectingblood pressure in population groups. Trans Assoc Am Physicians 1968; 81: 135-46.

${ }^{11}$ Grollman A. A conjecture about the prevalence o⿺ essential hypertension and its incidence in the Black Tex Rep Bio Med 1978; 36: 25-32.

${ }^{12}$ Miall WE. Follow-up study of arterial pressure in the population of a Welsh mining valley. $\mathrm{Br}$ Med J 1959; ii, 1204-10.

${ }^{13}$ Boyle $\mathrm{E}$ Jr. Biological patterns in hypertension by race, sex, body weight and skin colour. JAMA 1970; 213: $1637-43$.

${ }^{14}$ Prior AM, Evans JG, Harvey HPB, Davidson F, Lindsey $M$. Sodium intake and blood pressure in two Polynesian populations. $N$ Engl J Med 1968; 279: 515-20.

${ }^{15}$ Pickering GW, Roberts JAF, Sowry GSC. Aetiology of essential hypertension: effect of correcting for arm circumference on growth rate of arterial pressure with age. Clin Sci 1954; 13: 267-71.

${ }^{16}$ Shaper AG, Leonard PJ, Jones KW, Jones $M$. Environmental effects on the body build, blood pressure and blood chemistry of nomadic warriors serving in the army in Kenya. E Afr Med J 1969: 46: 282-9.

${ }^{17}$ Maddocks I. Blood pressure in Melanesians. Med J Aust 1967; 1: 1123-6.

${ }^{18}$ Sever PS, Peart WS, Gordon D, Beighton P. Blood pressure and its correlates in urban and tribal Africa. Lancet 1980; ii: 60-4.

${ }^{19}$ Rose GA, Blackburn H. Cardiovascular survey methods. Geneva: World Health Organisation, 1968; 94-5. 